\section{An Abstracting Service for Human Biology}

THE trustees of Biological Abstracts announce the establishment, beginning in January 1946, of a new section-Section H, specially assembled Abstracts of Human Biology-intended for anthropologists, sociologists, psychologists, nourologists and psychiatrists, students of child development and human welfare, and students of man generally. The new section will be an assemblage of all abstracts published in Biological Abstracts dealing with the broad field of human and social biology. Biological studies on human inheritance, population and fertility, endocrine and nourological factors affecting growth, development and human personality, aleoholism and drug addiction, and nervous disorders and mental deficiencies, and broad nutritional and epidemiological studies affecting human welfare, are some of the many fields that will be covered. Further information may be obtained from Mr. H. I. Anderson, Biological Abstracts, University of Pennsylvania, Philadelphia 4, Pennsylvania.

\section{Survival of a Fish after a Major Injury}

A POPUlar article by Elizabeth C. Pope in The Australian Museum Magazine (8, No. 11, 383) records the survival of a specimen of Meuschenia skottowei after the loss (at some previous date in its existence) of three fifths of the tail end of its body. The fish was swimming in the customary position when it was caught in Port Jackson. A photograph of the specimen shows an interesting modification of what, originally, must have been mere remnants of the dorsal and ventral fins. These appear to have grown backwards and round the severed end of the body in order, apparently, to compensate for the loss of the tail as a propelling organ. Dissection showed that the back had been severed clean between vertebræ, and in such a position that little more than the head remained. Most of the gut, though intact, was found to be displaced, and, though the internal organs were crowded, the swim-bladder appeared normal. At least two of the major bloodvessels must have been severed at the time of the accident; but death by hæmorrhage was evidently prevented by crushed tissue sealing the cut ends.

\section{University of London Appointments}

Dr. KarL Mannheim has been appointed to the University chair of education tenable at the Institute of Education as from October 1, 1945. Since 1933 he has been lecturor in sociology at the London School of Economics and since 1.941 he has been attached to the staff of the Institute of Education.

Dr. Walter Freudenthal has been appointed to the University readership in dermatological histology tenable at University Coll эge Hospital Medical School as from October 1, 1945. Since 1934 he has been research worker and assistant to the Dermatological Department of the School.

The title of professor emeritus in morbid anatomy in the University has been conferred on Prof. G. W. de P. Nicholson, who was University professor of morbid anatomy at Guy's Hospital Medical School during 1922-44.

Dr. D. M. Newitt, reader in chemical technology at the Imperial College of Science and Technology since 1937, and since 1941 director of scientific research of the Inter-Services Research Bureau, has been appointed to the Courtaulds chair of chemical engineering tenable at the College as from October 1.
Dr. Alan Moncrieff, of the Middlesex Hospital and the Hospital for Sick Children, has been appointed to the Nuffield chair of child health tenable at the Institute of Child Health as from January 1, 1946.

\section{Royal Geographical Society Christmas Lectures}

The two Christmas lectures of the Royal Geographical Society will explain in non-technical terms the evolution of survey and map-production methods down to the advances achieved during the War. On December 31, Major C. A. Hart will speak on "Modern Maps and how they are Made", and on January 4, Dr. Edward Lynam, in charge of the Map Room of the British Museum, will deal with some "Early Map Makers", and early methods of surveying from the time of the fourteenth century. The lectures will be supplemented by an exhibition which will be open during December 31-January 5 in the Society's House, Kensington Gore, London, S.W.7.

\section{Physical Society's Exhibition}

THE thirtieth Exhibition of Scientific Instruments and Apparatus, arranged by the Physical Society, will be held at the Imperial College of Science and Technology, Imperial Institute Road, South Kensing. ton, S.W.7, on January 1 (2.30 p.m.-9 p.m.), January 2 (4 p.m. -9 p.m.) and January 3 (2.30 p.m. -9 p.m.). The leading manufacturers of scientific instruments will be exhibiting their latest products in the Trade Section. The Research and Educational Section will contain contributions from research laboratories, and experiments of educational interest. Discourses will be delivered on January 1 at 5.30 and 8.15 p.m., on "The Optical Industry in the War", by Captain T. Martin ; on January 2, at 5.30 and 8.15 p.m., on "Radar", by Sir Edward Appleton; on January 3, at 5.30 and 9 p.m., on "Modern Plastics and Cements", by Dr. J. C. Swallow. Admission to the Exhibition is by ticket only. Members of institutions and scientific societies may obtain tickets from their secretaries; tickets may also be obtained direct from the Exhibition Secretary, I Lowther Gardens, Exhibition Road, S.W.7.

\section{Announcements}

Prof. Artwuri Vrrtanen, of the Biochemical Institute, Helsinki, has been awarded the Nobel Prize for Chemistry for 1945.

THE managers of the Royal Institution have appointed Prof. Eric K. Rideal, professor of colloid science in the University of Cambridge, to be Fullerian professor of chemistry in the Royal Institution and director of the Davy Faraday Research Laboratory, in succession to Sir Henry Dale, who retires from both posts on September 30, 1946.

Prof. H. A. Krebs has received a message from Dr. T. Bücher, who worked with Prof. Otto Warburg, stating that Prof. Warburg is alive and well. Apparently Prof. Warburg went to his country house on the Island of Rügen in January 1945, and returned to Berlin in June.

THE foundation members of the newly formed Medical Academy of Sciences of the U.S.S.R. met recently to vote for the first elected members and corresponding members of the Academy. Among those elected to membership were A. E. Braunstein, N. R. Rogansky, R. R. Timofeevsky, P. K. Anochin, D. N. Nasonov and N. F. Gamalea. 